\title{
EVALUATING PUBLIC TRANSPORT SOCIAL EXCLUSION IN GUADALAJARA, MEXICO
}

\author{
CARMEN LIZÁRRAGA ${ }^{1 *}$, ALEJANDRO L. GRINDLAY ${ }^{2 \dagger}$ \& GABRIELA OCHOA-COVARRUBIAS ${ }^{3 \ddagger}$ \\ ${ }^{1}$ Applied Economics Department, Faculty of Business and Economics, University of Granada, Spain \\ ${ }^{2}$ Department of Urban and Regional Planning, University of Granada, Spain \\ ${ }^{3}$ Habitat and Urban Development Department, ITESO, Jesuit University of Guadalajara, Mexico
}

\begin{abstract}
The role of the public transport system as promoter of social inclusion is gaining increasing attention in the fields of transport policy and planning. This is especially relevant in areas traditionally characterized by high levels of poverty and structural inequalities where it can be a decisive element in the reduction of social exclusion. This paper evaluates the topic through an innovative methodology based on index comparison. Firstly, a traditional accessibility index is used which considers the access time to public transport stops, and secondly an Index of Transport Social Disadvantage is proposed. It includes the transport disadvantage factors of the populations, such as disability, old age, low income, unemployment and pre-school children. These transport disadvantage characteristics have been divided into two groups: the first includes the disadvantage characteristics distributed equally. In the second group, the disadvantaged groups in transport with an unequal territorial distribution are taken into account. The Gini index is used to ascertain the differences in these groups. This method facilitates the identification of the unequal distribution of transport disadvantage and therefore, social exclusion. The consideration of the two indexes, access time and transport social disadvantages, will find the areas not only with low accessibility levels, but also with high levels of population with transport disadvantages, thereby assessing social exclusion linked with public transport. This methodology is applied to the public operated transport system of the Guadalajara Metropolitan Area, Mexico. Its development reveals which areas are affected by the under provision of public transport as well as the population characterized by transport social disadvantage, which together give a clear indicator of the situation of social exclusion linked to the public transport system.
\end{abstract}

Keywords: social exclusion, access time disadvantage, transport social disadvantage, Guadalajara.

\section{INTRODUCTION}

It is well recognized that the ability to travel is a basic need which allows access to other elementary and auxiliary necessities [1]-[3]. Mobility-related social exclusion is a situation where the transport system is inadequate or even non-existent. In these cases, people are limited in access to economic or social activities, resulting in fewer opportunities [4]-[8]. An unsatisfactory transport system is thus an important factor in triggering social exclusion [9]-[11].

The role of the public transport system as promoter of social inclusion is gaining increasing attention in the fields of transport policy and planning [12]. This is especially relevant in a context traditionally characterized by high levels of poverty and structural inequalities. The provision of transport is directly related to the access time to reach the stations/stops. Moreover, some socioeconomic characteristics affect the intensity of the disadvantage of transport, even more so if the spatial distribution is uneven. Hence, to avoid social exclusion, a transportation system should be satisfactory for users with these kind of socioeconomic characteristics [13].

*ORCID: http://orcid.org/0000-0002-3221-6178

†ORCID: http://orcid.org/0000-0001-5176-0550

$\ddagger$ ORCID: http://orcid.org/0000-0002-2864-6634

WIT Transactions on The Built Environment, Vol 200, (C) 2020 A. L. Grindlay published by WIT Press under CCBY4.0 www.witpress.com, ISSN 1743-3509 (on-line)

doi:10.2495/UT200161 
Most of the empirical evidence of transport exclusion in Latin America is concentrated in South America [13]. There are few published papers or reports regarding this topic in the Guadalajara Metropolitan Area (GMA) [14]-[17]. To fill this gap, this paper describes the evaluation of social exclusion through an innovative methodology based on dual index comparison, i.e. Index of Access Time Disadvantage (IATD) and Index of Transport Social Disadvantage (ITSD).

This paper is structured as follows. In this section we describe the problem, the lack of empirical analysis from case study and how we fill this gap. In Section 2 we describe the methodological approach and the study area. Next, in Section 3 we discuss the spatial patterns of the relationship between social and transport disadvantages in the urbanized area of GMA. Finally, we derive our conclusions from this research in Section 4.

\section{METHODOLOGY}

Based on previous research [3], [18]-[22], this study uses index comparison to examine social exclusion in relation to transport. Scrutiny of the IATD and the ITSD identifies not only the areas with low accessibility levels, but also with high levels of transport social disadvantages, and thereby allows the assessment of social exclusion linked with public transport. The study was carried out in the Guadalajara Metropolitan Area (GMA), Mexico, and was focused on the public operated transport system.

As shown in Fig. 1, the GMA is an area of nine municipalities with 4.8 million inhabitants [23]. More than half of them live only in two municipalities, that is, Guadalajara and Zapopan, with $30 \%$ and $27 \%$ of the GMA population, respectively. The peripheral area is mainly rural with low population density, except for the municipal capitals. The metropolitan mobility investments have traditionally favored the automobile infrastructure over the mass transport system [24]. The public operated mass transport system is known as SITEUR. It includes four modes of transport, i.e. light rail transit (LRT), bus rapid transit (BRT), trolley and bus. It mainly serves the central area of the metropolis with nearly half a million daily

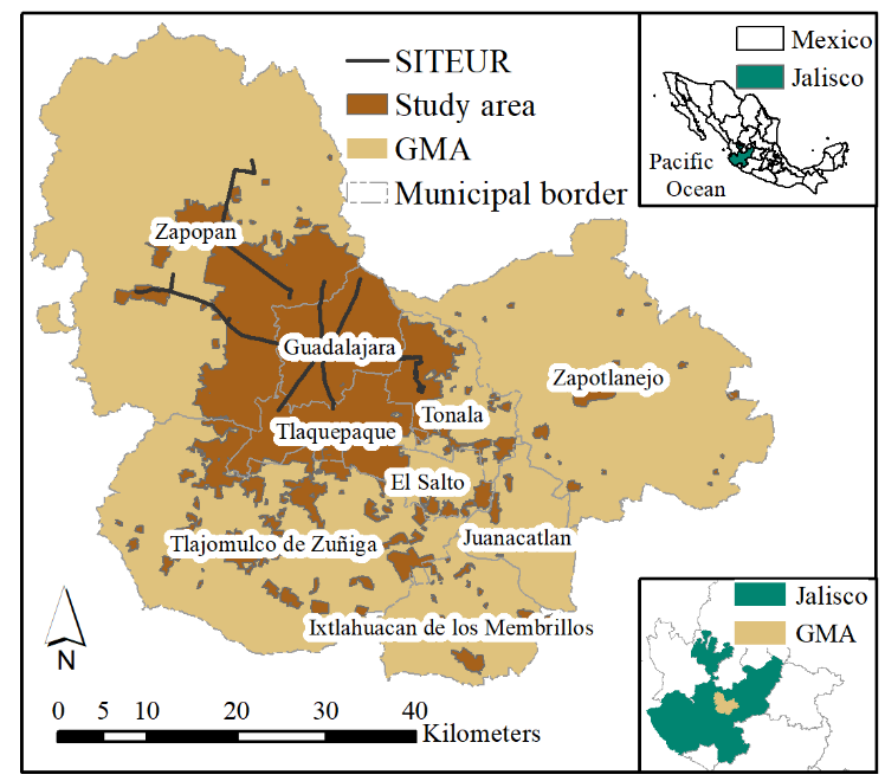

Figure 1: Urbanized area of the Guadalajara Metropolitan Area. 
journeys [25], while other areas are served by low quality privately-operated buses, microbuses and other flexibly structured transit systems [16], [24]. Since transportation is a metropolitan issue [26], this study includes the nine municipalities, despite the enormous differences in the coverage by the SITEUR service and in their socioeconomic characteristics.

The IATD was calculated based on distance between the stops/stations and the basic spatial unit of analysis, i.e. the Geoelectoral Section (GS). ArcGis ${ }^{\circledR}$ was the geographic information system used for this network analysis. Two assumptions were made. First, the centroid of the GS was used for the service area calculations. Second, if a GS had several transport mode options at a distance of less than 5 minutes, the mode with the highest hierarchy was chosen, i.e. first the LRT, followed by the BRT, then the trolley and finally the bus.

The ITSD was designed and calculated with social factors in relation with transport [13]. The characteristics of disadvantage in transport were divided into two groups with the Gini Index. In the first group, the students, elderly and non-social security population were equally distributed in the territory. The second group takes into consideration the transport disadvantage factors of, disability, unemployment, non-private-owned car, pre-school children (0-5), lack of refrigerator and illiteracy [27], which are unequally distributed in the territory.

The ITSD was calculated with the second group of characteristics by the means of eqn (1)

$$
\operatorname{ITSD}=\sum_{j=1}^{6} \text { ITDij. }
$$

The ITDij represents the transport handicap index in section $\mathrm{i}$ for the handicap condition $\mathrm{j}$. The data were ordered according to the condition of disadvantage $\mathrm{j}$ from lowest to highest and divided by quintiles according to population. The ITDij could take three values. It took the value 0 , low disadvantage, when the population of district $i$ was in the lowest $20 \%$ of disadvantage. It took the value 2 when the population of district i was in the top $20 \%$ of disadvantage. And took a value of 1 for the rest. Each district $i$ took a value for each of the six unequally distributed transport disadvantage conditions. Thus, the index ITD represents the sum of ITDi from $\mathrm{j}=1$ to 6 . And it can take values from 0 : low disadvantage in all conditions; to 12 with high disadvantage in all indicators of transport disadvantage. Finally, the IATD was overlapped with the ITSD and the temporary disadvantage in access to transport supply. As a result, areas of social and public transport exclusion were identified.

$$
3 \operatorname{ITSD}=\sum_{j=1}^{6} \text { ITDIJ. RESULTS AND DISCUSSION }
$$

The indexes assessment was mapped and spatial patterns were identified. In accordance with previous studies [3], [16], [28], results highlight higher access time and transport social disadvantages in the non-central areas of the GMA, especially the southeast.

Fig. 2 maps the sum of social factors used to calculate the ITSD. Average values cover almost the entire city, except for three areas: the northwest of the city center of Guadalajara, where some of the residential areas with the highest real estate value are located, has lower transport social disadvantages; the eastern area dissected with the metropolis core; and finally, a red small red area within the yellow which is an irregular settlement known as "Cerro del Cuatro" with high socioeconomic disadvantages.

Fig. 3 shows the normalization and both indexes. On the one hand, it can be seen that around SITEUR the IATD is low and it is distributed over $14 \%$ of the developed area, with an average degree of disadvantage occupying $51 \%$ of the area and the high IATD occupying 


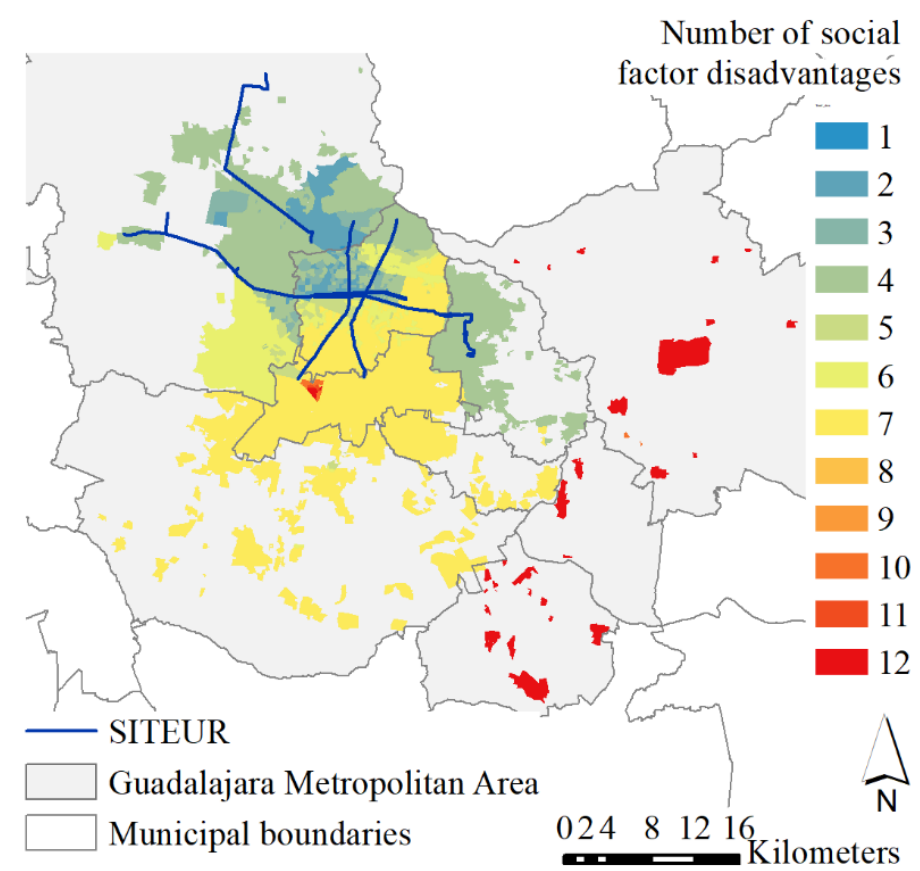

Figure 2: Number of social factor disadvantages in relation with transport.
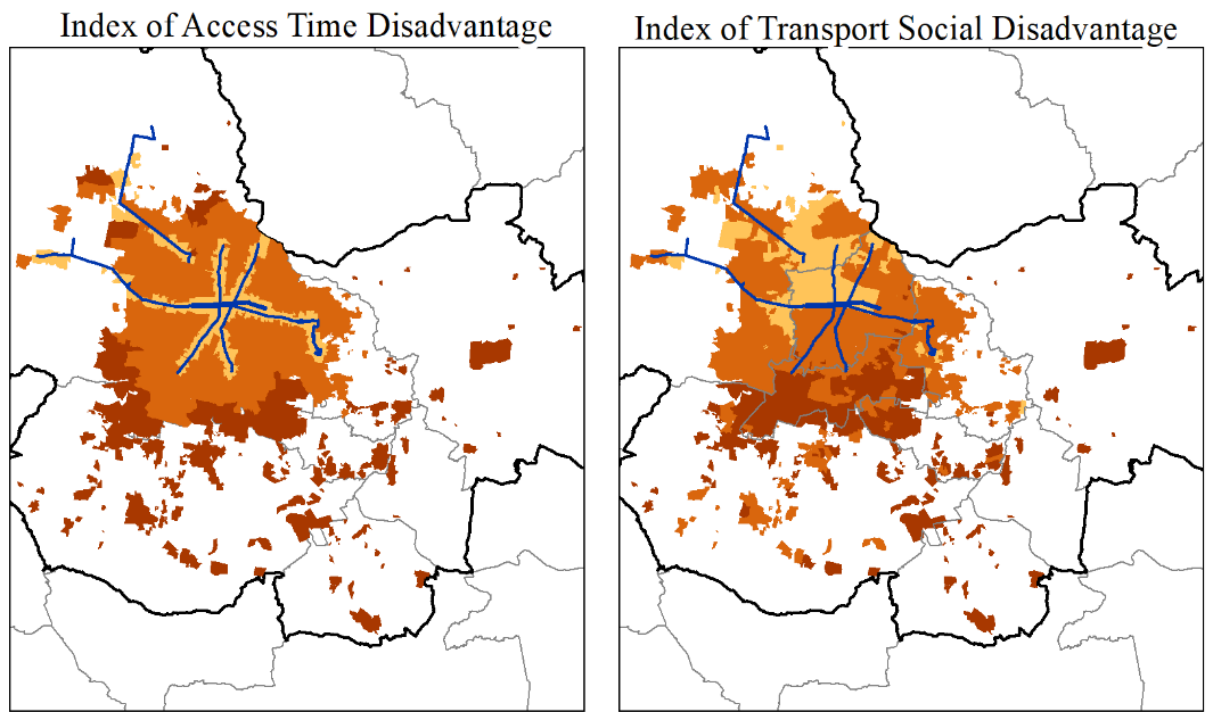

Grade of Disadvantage
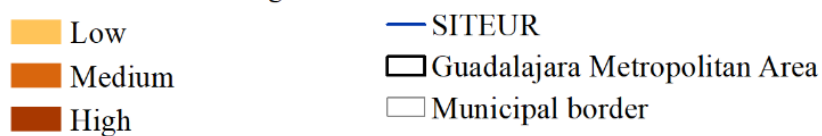

\begin{tabular}{llll}
0 & 4 & 8 & 16 \\
\hline
\end{tabular}

Figure 3: Indexes of access time disadvantage and transport social disadvantage. 
Table 1: Surface per index grade.

\begin{tabular}{|c|c|c|c|c|c|}
\hline & $\begin{array}{c}\text { Grade of } \\
\text { disadvantage } \\
(80 / 20)\end{array}$ & $\begin{array}{c}\text { Time } \\
\text { disadvantage } \\
\text { surface }\left(\mathrm{m}^{2}\right)\end{array}$ & Surface $(\%)$ & $\begin{array}{c}\text { Transport } \\
\text { disadvantage } \\
\text { surface }\left(\mathrm{m}^{2}\right)\end{array}$ & Surface (\%) \\
\hline & 0 & $106,876,144$ & $14 \%$ & $599,807,878.56$ & $18 \%$ \\
\hline & 1 & $391,091,989$ & $51 \%$ & $1,190,489,183.75$ & $35 \%$ \\
\hline & 2 & $268,680,443$ & $35 \%$ & $1,592,670,988.82$ & $47 \%$ \\
\hline & Total & $766,648,577$ & & $3,382,968,051.13$ & \\
\hline
\end{tabular}

a dispersed area of $35 \%$ of the territory. On the other hand, the lowest value of the ITSD occupies $18 \%$ of the surface and is located in the northwest, those of medium disadvantage occupy $35 \%$ of the territory and are in the center, while the high social disadvantage of transport occupies $47 \%$ of the surface and is dispersed in the southeast (Table 1). The system does not reach these areas as it is no feasible to serve such dispersed urbanized areas [29].

As shown in Fig. 4, almost all the urban areas of the municipalities of El Salto, Ixtlahuacán de los Membrillos, Juanacatlán, Tajomulco de Zúñica and Zapotlanejo were evaluated as highly disadvantaged in both indexes. This coincides with the perception that, although these municipalities formally belong to the metropolitan area, there are still structural differences that exclude them from the transportation benefits offered in the other four municipalities [30]. Even if SITEUR does not serve the southern areas of the GMA, the proximity of the LRT and the BRT helps to reduce social exclusion in this area. According to Ríos [24], results highlight the need to build an orderly network and integrate mass transport in the GMA. Fig. 4 also shows that the edge of the Periférico (a 12-lane avenue) is a barrier to both the time of access to transport and the social disadvantage of transport. It highlights that SITEUR improves access to the population in the south with transport disadvantages, since it balances out time those with greater social disadvantages. Therefore, the SITEUR bus network should be expanded and the quality of the privately-operated bus network should be improved, and another structured flexible transit system could be advisable for low demand for these areas [31].

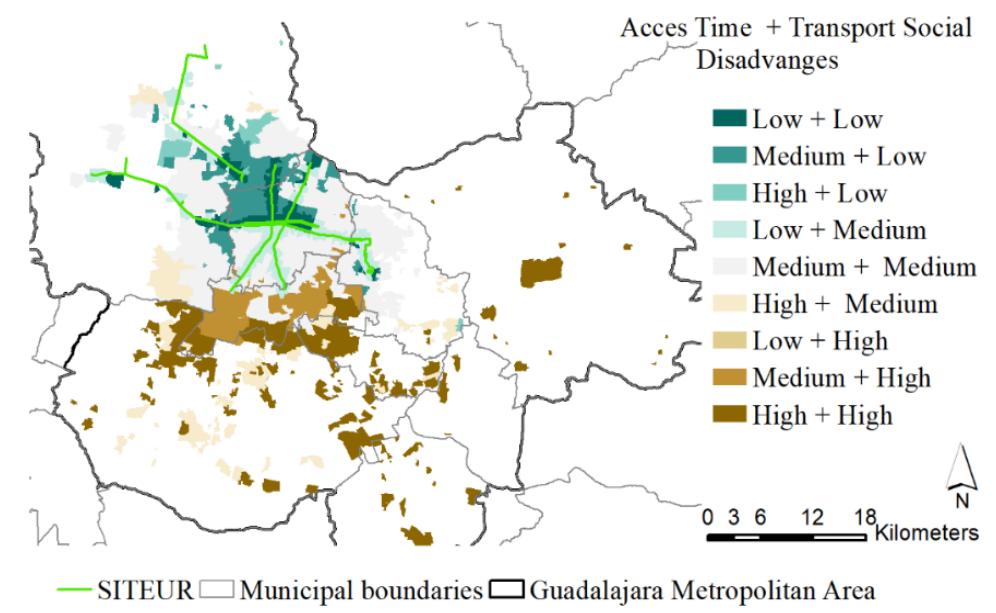

Figure 4: Overlap of indexes of access time disadvantage and transport social disadvantage. 


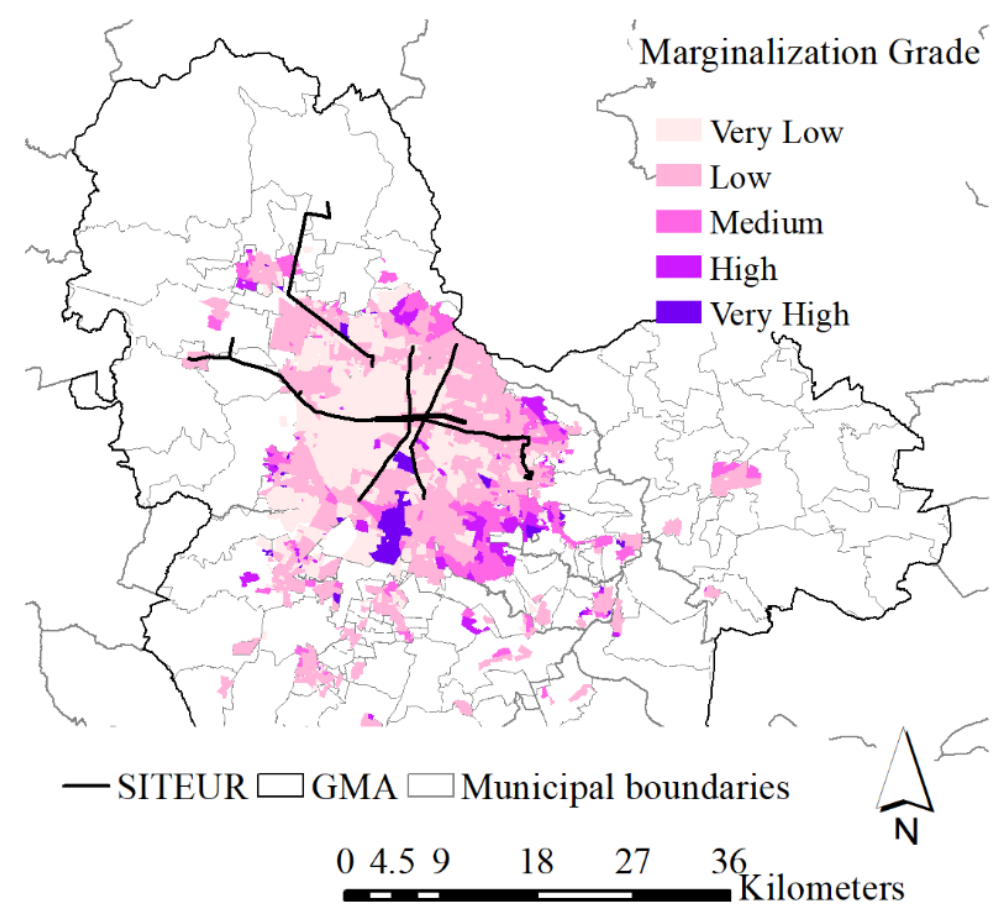

Figure 5: Marginalization grade at neighborhood scale.

These results are consistent with the general socioeconomic reality of GMA as it can be seen with respect to the mapped official marginalization grades [32] (Fig. 5).

On one hand, the strength of this study is its capacity to explain of a complex phenomenon with a relatively simple methodology. Moreover, this methodology can be transferred to other cities and be used for comparative studies over time. On the other hand, the study lacks updated data, due to their availability. Consequently, future research will recalculate the indices after the next population and housing census. Likewise, it is expected that social exclusion will be reduced with new mass transportation lines under construction, as well as the improvement of the quality of privately-operated bus and flexible transit systems in noncentral areas.

\section{CONCLUSIONS}

The link between public transport systems and social inclusion is well recognized. Nevertheless, there is little empirical evidence of this relationship in Mexico, a country characterized by structural inequalities. Thus, the innovative methodology developed and applied to the GMA, Mexico is an advance in the empirical demonstration of this relationship. This study has made it possible to identify that the most socially disadvantaged inhabitants are not adequately served by the public transport system SITEUR. This is clearly revealed with the calculated indicator of social exclusion related with SITEUR.

The analysis was carried out through the design and calculation of two indexes. First, the IATD, a temporal disadvantage based on walking time to the SITEUR's station/stop nearest to the dwelling and, second, a multivariate ITDI based on socioeconomic factors unequally distributed in the territory. Official open access data were introduced to basic statistical and 
Geographic Information Systems tools. The results match with previous academic studies obtained with qualitative methods showing that the non-central areas of the Latin-American cities are the most socially excluded.

It can be concluded that SITEUR improves the time of access to public transport, but it is insufficient to serve the Southeast which has a high transport social disadvantage. This is understood by the difficulty of serving fragmented areas with mass transport. Thus, it is suggested to increase the SITEUR quality bus network, to improve the quality of the privately-operated bus network and other structured flexible transit systems for low demand for these areas. In addition, the mass transportation line planned to connect the international airport (at the south east of the GMA) will reduce the disadvantages in that area in the future.

\section{ACKNOWLEDGEMENTS}

With thanks to the National Council of Science and Technology (CONACYT), Mexico, the Development Trust of Mexico (FIIDEM) and of ITESO, the Jesuit University of Guadalajara for partially funding this research.

\section{REFERENCES}

[1] Cass, N., Shove, E. \& Urry, J., Social exclusion, mobility and access. The Sociological Review, 53(3), pp. 539-555, 2005. https://doi.org/10.1111/j.1467-954X.2005.00565.x.

[2] Sager, T., Freedom as mobility: Implications of the distinction between actual and potential travelling. Mobilities, 1(3), pp. 465-488, 2006. https://rsa.tandfonline.com/doi/abs/10.1080/17450100600902420.

[3] Jaramillo, C., Lizárraga, C. \& Grindlay, A.L., Spatial disparity in transport social needs and public transport provision in Santiago de Cali (Colombia). Journal of Transport Geography, 24, pp. 340-357, 2012. https://doi.org/10.1016/j.jtrangeo.2012.04.014.

[4] Kenyon, S., Tackling transport-related social exclusion: Considering virtual access to opportunities, services and social networks. New Technology in the Human Services, 14(3/4), pp. 10-22, 2002.

[5] Kenyon, S., Lyons, G. \& Rafferty, J., Transport and social exclusion: investigating the possibility of promoting inclusion through virtual mobility. Journal of Transport Geography, 10(3), pp. 207-219, 2002.

[6] Preston, J. \& Rajé, F., Accessibility, mobility and transport-related social exclusion. Journal of Transport Geography, 15(3), pp. 151-160, 2007.

[7] Hine, J. \& Mitchell, F., Transport Disadvantage and Social Exclusion: Exclusionary Mechanisms in Transport in Urban Scotland, Routledge: London, 2016.

[8] Kamruzzaman, M., Yigitcanlar, T., Yang, J. \& Mohamed, M.A., Measures of transport-related social exclusion: A critical review of the literature. Sustainability, 8(7), p. 696, 2016.

[9] Lizárraga, C., Metropolitan expansion and mobility: The case of Caracas. Eure-Revista Latinoamericana de Estudios Urbano Regionales, 38(113), pp. 99-125, 2012.

[10] Özkazanç, S. \& Özdemir Sönmez, F.N., Spatial analysis of social exclusion from a transportation perspective: A case study of Ankara metropolitan area. Cities, 67, pp. 74-84, 2017.

[11] Quevedo García, F., Asprilla Lara, Y. \& González Pérez, M.G., Entropías de la movilidad urbana en el espacio metropolitano de Guadalajara: Transporte privado y calidad del aire. Tecnura: Tecnología y Cultura Afirmando el Conocimiento, 21(53), pp. 138-140, 2017.

[12] Davoudi, S. \& Bell, D. (eds), Justice and Fairness in the City: A Multi-Disciplinary Approach to "Ordinary" Cities, Policy Press: Bristol, 2016. 
[13] Vecchio, G., Tiznado-Aitken, I. \& Hurtubia, R., Transport and equity in Latin America: A critical review of socially oriented accessibility assessments. Transport Reviews, 40(3), pp. 1-28, 2020. https://doi.org/10.1080/01441647.2020.1711828.

[14] Córdova España, M., Movilidad urbana sustentable para la zona conurbada de Guadalajara. Guadalajara, Universidad de Guadalajara: México, pp. 393-429, 2007.

[15] Observatorio de Movilidad Urbana, Banco de Desarrollo de América Latina, CAF. omu-caf-guadalajara-2015.xlsx， 2015. https://scioteca.caf.com/handle/123456789/ 420. Accessed on: 1 Apr. 2020.

[16] Calonge Reillo, F. \& Aceves Arce, R.H., Viajando por sectores no centrales del área metropolitana de Guadalajara, México. La escasez de recursos y de alternativas de transporte como condicionantes de la exclusión social. Sociológica, 34(96), pp. 137$168,2019$.

[17] Jalisco Cómo Vamos, Moverse en GDL. Jalisco Cómo Vamos, 2019. www.jaliscocomovamos.org/moverse-en-gdl. Accessed on: 15 Apr. 2020.

[18] Xia, J., Nesbitt, J., Daley, R., Najnin, A., Litman, T. \& Tiwari, S.P., A multidimensional view of transport-related social exclusion: A comparative study of Greater Perth and Sydney. Transportation Research Part A: Policy and Practice, 94, pp. 205221, 2016.

[19] Grindlay, A.L., Jaramillo, C. \& Lizárraga, C., Spatial relationships between mobility opportunities and constraints of transport disadvantages: The case of Santiago de Cali, Colombia. WIT Transactions on the Built Environment, vol. 176, WIT Press: Southampton and Boston, pp. 119-129, 2017. http://dx.doi.org/10.2495/UT170111.

[20] Vicuña, M., Orellana, A., Truffello, R. \& Moreno, D., Integración urbana y calidad de vida: disyuntivas en contextos metropolitanos. Revista INVI, 34(97), pp. 17-47, 2019.

[21] Su, S., Zhou, H., Xu, M., Ru, H., Wang, W. \& Weng, M., Auditing street walkability and associated social inequalities for planning implications. Journal of Transport Geography, 74, pp. 62-76, 2019.

[22] Humberto, M., Laboissière, R., Giannotti, M., Marte, C.L., Cruz, D.A. \& Primon, H., Walking and walkability: Do built environment measures correspond with pedestrian activity? Ambient Construido, 19(4), pp. 23-36, 2019.

[23] INEGI (National Institute of Statistics and Geography Mexico), Número de habitantes, Jalisco. http://cuentame.inegi.org.mx/monografias/informacion/jal/poblacion/. Accessed on: 14 Apr. 2020.

[24] Ríos, A.A., El transporte público en el área metropolitana de Guadalajara: agenda, proyectos y "gatopardismo". Revista Mexicana de Análisis Politico y Administración Pública, 7(1), pp. 11-32, 2018.

www.remap.ugto.mx/index.php/remap/article/view/241.

[25] Saavedra, V., Los 275 mil viajes por día del Tren ligero, representan un mínimo aporte para la movilidad. El Occidental, 8 Feb., 2020. www.eloccidental.com.mx/local/los275-mil-viajes-por-dia-del-tren-ligero-representan-un-minimo-aporte-para-lamovilidad-4810557.html.

[26] Castañón Reyes, H.E., Caracterizacion_del_ciudadano_metropolit.pdf. Guadalajara, México: UN-Habitat - Gobierno del Estado de Jalisco, 2016.

[27] INEGI (National Institute of Statistics and Geography Mexico), SCINCE 2010 website. http://gaia.inegi.org.mx/scince2/viewer.html. Accessed on:24 Mar. 2020.

[28] Barranco-Ruiz, Y., León, C.C., Villa-González, E., Leal, X.P., Chillón, P. \& Rodríguez-Rodríguez, F., Active commuting to university and its association with sociodemographic factors and physical activity levels in Chilean students. Medicina (Lithuania) 55(5), 2019. 
[29] Vuchic, V.R., Urban Transit: Operations, Planning, and Economics, John Wiley \& Sons: New Jersey, 2005.

[30] IMEPLAN (Metropolitan Planning Institute, Guadalajara, Mexico), Plan de Ordenamiento Territorial Metropolitana del AMG, 2016. http://imeplan.mx/sites/default/files/IMEPLAN/POTmet_IIIFB-BajaRes.pdf. Accessed on: 15 Apr. 2020.

[31] Nourbakhsh, S.M. \& Ouyang, Y., A structured flexible transit system for low demand areas. Transportation Research Part B: Methodological, 46(1), pp. 204-216, 2012.

[32] IIEGJal (Institute of Statistical and Geographic Information of the State of Jalisco, Mexico), Grado de marginación por colonia, 2010.

https://datos.jalisco.gob.mx/dataset/grado-de-marginacion-por-colonia. Accessed on: 29 Apr. 2020. 